\title{
We Want to Hear from You
}

Theology Cataloging Bulletin (TCB) is a publication of Atla Open Press. Since its inception in 1992, the Bulletin has informed technical services librarians in the field of religion and theology of new developments and upcoming opportunities to support their work and professional development. In the past, $T C B$ focused mostly on cataloging, but now we want to expand coverage to a broader range of technical services activities, supporting Atla's mission to be collectors and connectors in religion and theology.

The $T C B$ editorial team invites you to participate in a survey that reviews the current publication and asks how it could be more valuable to you and your daily work activities. The responses will help guide the future direction of the Bulletin so we can offer the most helpful information to those who provide description of, and access to, library resources in religion and theology.

Please complete the survey by November 30, 2020. The TCB editorial team thanks you for your feedback. 